Article

\title{
Imidazo[1,2-b]pyrazole-7-carboxamides Induce Apoptosis in Human Leukemia Cells at Nanomolar Concentrations
}

\author{
Gábor J. Szebeni ${ }^{1,2} \oplus$, József A. Balog ${ }^{1}$, András Demjén ${ }^{3}$, Róbert Alföldi ${ }^{3}$, Vanessza L. Végi ${ }^{1,3}$, \\ Liliána Z. Fehér ${ }^{3}$, Imola Mán ${ }^{3}$, Edit Kotogány ${ }^{1}$, Barbara Gubán ${ }^{4}$, Péter Batár ${ }^{5}$, \\ László Hackler Jr. ${ }^{3}$, Iván Kanizsai ${ }^{3}$ D and László G. Puskás ${ }^{1,3, *}$ \\ 1 Laboratory of Functional Genomics, Biological Research Centre, Hungarian Academy of Sciences, \\ Temesvári krt. 62, H-6726 Szeged, Hungary; g.szebeni@avidinbiotech.com (G.J.S.); \\ jozsef.a.balog@gmail.com (J.A.B.); vegi.vanessza@gmail.com (V.L.V.); kotogany.edit@brc.mta.hu (E.K.) \\ 2 Department of Physiology, Anatomy and Neuroscience, Faculty of Science and Informatics, University of \\ Szeged, Közép fasor 52, H-6726 Szeged, Hungary \\ 3 Avidin Ltd., Alsó kikötő sor 11/D, H-6726 Szeged, Hungary; a.demjen@avidinbiotech.com (A.D.); \\ r.alfoldi@avidinbiotech.com (R.A.); 1.feher@avidinbiotech.com (L.Z.F.); \\ i.noktaman@avidinbiotech.com (I.M.); hackler@avidinbiotech.com (L.H.J.); \\ i.kanizsai@avidinbiotech.com (I.K.) \\ 4 Department of Dermatology and Allergology, University of Szeged, Korányi fasor 6, H-6720 Szeged, \\ Hungary; gubanbarbi@gmail.com \\ 5 Department of Hematology, Institute of Internal Medicine, University of Debrecen, Nagyerdei Körút 98, \\ 4032 Debrecen, Hungary; pbatar@med.unideb.hu \\ * Correspondence: laszlo@avidinbiotech.com; Tel.: +36-6220-2107
}

Academic Editor: Wolfgang Holzer

Received: 29 September 2018; Accepted: 29 October 2018; Published: 1 November 2018

\begin{abstract}
Leukemia, the malignancy of the hematopoietic system accounts for $10 \%$ of cancer cases with poor overall survival rate in adults; therefore, there is a high unmet medical need for the development of novel therapeutics. Eight imidazo[1,2-b]pyrazole-7-carboxamides have been tested for cytotoxic activity against five leukemia cell lines: Acute promyelocytic leukemia (HL-60), acute monocytic leukemia (THP-1), acute T-lymphoblastic leukemia (MOLT-4), biphenotypic B myelomonocytic leukemia (MV-4-11), and erythroleukemia (K-562) cells in vitro. Imidazo[1,2-b]pyrazole-7-carboxamides hampered the viability of all five leukemia cell lines with different potential. Optimization through structure activity relationship resulted in the following $\mathrm{IC}_{50}$ values for the most effective lead compound DU385: $16.54 \mathrm{nM}, 27.24 \mathrm{nM}$, and $32.25 \mathrm{nM}$ on HL-60, MOLT-4, MV-4-11 cells, respectively. Human primary fibroblasts were much less sensitive in the applied concentration range. Both monolayer or spheroid cultures of murine 4T1 and human MCF7 breast cancer cells were less sensitive to treatment with 1.5-10.8 $\mu \mathrm{M} \mathrm{IC} \mathrm{I}_{50}$ values. Flow cytometry confirmed the absence of necrosis and revealed $60 \%$ late apoptotic population for MV-4-11, and 50\% early apoptotic population for HL-60. MOLT-4 cells showed only about $30 \%$ of total apoptotic population. Toxicogenomic study of DU385 on the most sensitive MV-4-11 cells revealed altered expression of sixteen genes as early $(6 \mathrm{~h})$, midterm $(12 \mathrm{~h})$, and late response $(24 \mathrm{~h})$ genes upon treatment. Changes in ALOX5AP, TXN, and SOD1 expression suggested that DU385 causes oxidative stress, which was confirmed by depletion of cellular glutathione and mitochondrial membrane depolarization induction. Imidazo[1,2-b]pyrazole-7-carboxamides reported herein induced apoptosis in human leukemia cells at nanomolar concentrations.
\end{abstract}

Keywords: imidazole; pyrazole; acute myeloid leukemia; apoptosis; toxicogenomics 


\section{Introduction}

Leukemias and lymphomas accounts for almost $10 \%$ of cancer cases worldwide [1]. Leukemias are heterogeneous diseases due to differential cellular origin along with self-characteristic genetic abnormalities [2]. The discussion of current therapies is beyond the scope of the present article. Although bone marrow transplantation reached a break-through in the last decades for the treatment of childhood leukemias, chemotherapy remains the main option for adults, and especially for the elderly with much less therapeutic success nowadays. Based on the maturation status, differentiation level, and/or lineage commitment acute myeloid leukemia cells (AML) have been classified by the French-American-British classification (FAB) system [3-5]. To determine the specificity of imidazo[1,2-b]pyrazole-7-carboxamides as potential anti-leukemic agents we have focused on the following differentially matured AML cells: HL-60 acute promyelocytic leukemia, (FAB M2) [6,7], MV-4-11 biphenotypic B myelomonocytic leukemia (FAB M4) [8,9], THP-1 acute monocytic leukemia (FAB M5) [10,11], K-562 erythroleukemia, (FAB M6) [12,13]. One acute lymphoblastic leukemia cell line (ALL), the MOLT-4 acute T-lymphoblastic leukemia, was also involved in the study.

Pyrazole derivatives are pharmacologically relevant active scaffolds in diverse therapeutic fields, reviewed recently by Karrouchi et al. [14]. Moreover, the synthesis and the anticancer activity of $N$-fused pyrazoles, such as imidazo[1,2-b]pyrazoles have also been reported $[15,16]$. We have recently published the synthesis of a library (67 compounds) of novel imidazo[1,2-b]pyrazole-7-carboxamides, where among different cell lines, HL-60 leukemia cells showed the highest sensitivity upon treatment [17]. Based on the previous structure-activity relationship (SAR) experience, hit molecules have been further optimized by changing certain substituents to increase the cytotoxic effect against different leukemia cells. These efforts resulted in more active compounds with anti-leukemic potential reported first in this study.

\section{Results}

\subsection{Synthesis of Imidazo[1,2-b]pyrazole-7-carboxamides}

Synthesis was performed by the previously presented manner via Groebke-Blackburn-Bienaymé three component reaction (GBB-3CR) [17]. Briefly, to a suspension of pyrazole precursor (0.50 mmol) in $\mathrm{MeCN}(0.5 \mathrm{~mL})$, pivaldehyde $(0.55 \mathrm{mmol}), \mathrm{HClO}_{4}(20 \mathrm{~mol} \%)$, and the corresponding isocyanide $(0.55 \mathrm{mmol})$ were added and stirred at room temperature for $6 \mathrm{~h}$. Then the crude mixture was purified by filtration followed by washing with cold $\mathrm{MeCN}$ or by column chromatography on silica gel (eluent: hexane/EtOAc) to afford pure imidazo[1,2-b]pyrazoles (Figure 1A). Seven DU-compounds were prepared for antitumor characterization with a substitution pattern of $\mathrm{C} 2$ tert-butyl $(t \mathrm{Bu}), \mathrm{C} 3$ aliphatic ( $t \mathrm{Bu}$, tert-octyl (tOctyl) or cyclohexyl (Cy)), and C7 phenyl substituted secondary carboxamides with electron-donating (ED) groups, such as hydroxyl $(\mathrm{OH})$ and amino $\left(\mathrm{NH}_{2}\right)$ functions (positioning in ortho-, meta- or para positions) (Figure 1B). In addition, one imidazo[1,2-b]pyrazole (DU283) incorporating electron-withdrawing (EWG) function in para position $\left(R^{1}=4-F\right)$ was selected among the investigated bicycles as an anti-tumor reference imidazo[1,2-b]pyrazole-7-carboxamide [17]. Spectral analysis of imidazo[1,2-b]pyrazole-7-carboxamides can be found in Figure S1.

\subsection{Imidazo[1,2-b]pyrazole-7-carboxamides Hampered the Viability of Leukemia Cells with Different Potential}

The substitutions chosen were based on the previously established structure-activity relationship (SAR) results [17], with the goal to design compounds with improved anti-leukemic effect. Seven compounds out of eight hampered the viability of all five tested leukemia cell lines with different potential. Superior efficiency was obtained for DU325 and DU385 (Table 1). The presence of $t \mathrm{Bu}$ as a bulky group in the $\mathrm{R}^{2}$ position in combination with 4- $\mathrm{NH}_{2}$ and $4-\mathrm{OH}$ moieties in the $\mathrm{R}^{1}$ determined the strength of anti-leukemic efficiency. In addition, the hydroxyl moiety located in para position on the aromatic ring $\left(\mathrm{R}^{1}=4-\mathrm{OH}\right)$ provided the highest cytotoxicity (DU385). Optimization 
resulted in the following $\mathrm{IC}_{50}$ values for the most effective lead compound DU385: $16.54 \mathrm{nM}, 27.24 \mathrm{nM}$, and $32.25 \mathrm{nM}$ on HL-60, MOLT-4, MV-4-11, respectively (Table 1).

$\mathbf{A}$

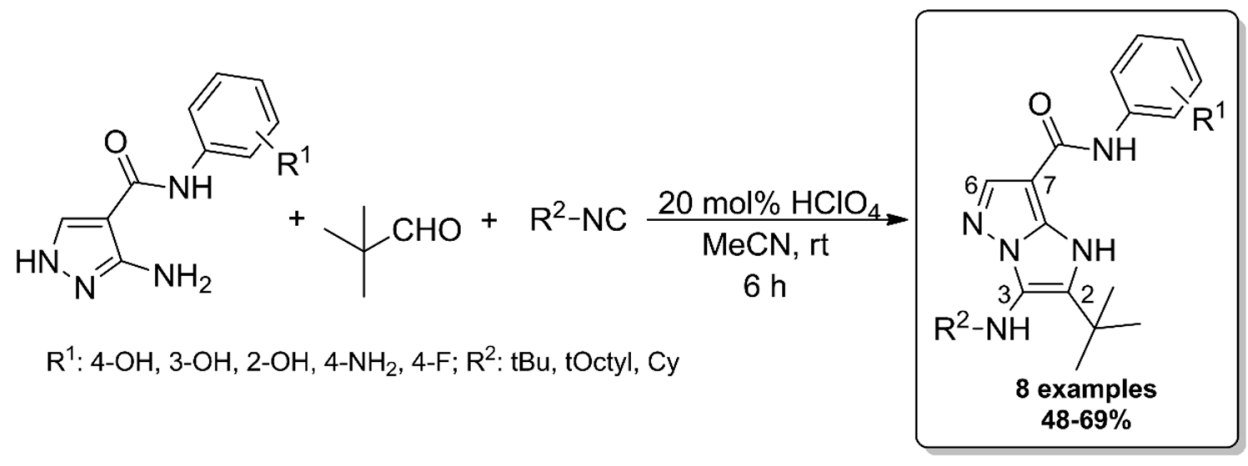

B

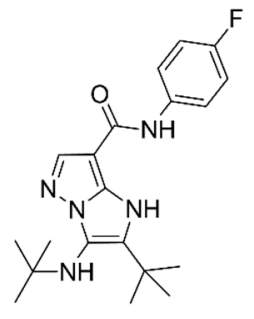

DU283<smiles>CC(C)(C)Nc1c(C(C)(C)C)[nH]c2c(C(=O)Nc3ccc(N)cc3)cnn12</smiles>

DU325<smiles>CC(C)(C)C(C)(C)C(C)(C)C</smiles>

DU385<smiles>CC(CC(C)(C)C)Nc1c(C(C)(C)C)[nH]c2c(C(=O)Nc3ccc(O)cc3)cnn12</smiles>

DU441<smiles></smiles>

Figure 1. (A) General procedure for the preparation of imidazo[1,2-b]pyrazoles via Groebke-BlackburnBienaymé three components reaction (GBB-3CR). (B) Structures of imidazo[1,2-b]pyrazole7-carboxamides.

Table 1. $\mathrm{IC}_{50}$ values $(\mathrm{nM})$ of analogs determined by resazurin assay upon treatment by imidazo[1,2-b]pyrazole-7-carboxamides.

\begin{tabular}{ccccccc}
\hline & HL-60 & MOLT-4 & MV-4-11 & THP-1 & K-562 & Human Fibroblasts \\
\hline DU283 & 266.9 & 146.2 & 209.4 & 352.5 & 493.7 & n.d. \\
DU325 \# & 66.31 & 39.35 & 50.21 & 73.78 & 194.9 & n.d. \\
DU385 \# $^{\text {DU }}$ & 16.54 & 27.24 & 32.25 & 25.88 & 54.31 & n.d. \\
DU441 $^{\#}$ & 62.04 & 60.48 & 87.56 & 94.9 & 190.9 & n.d. \\
DU442 & "58.71 & 51.03 & 68.08 & 95.22 & 163.6 & n.d. \\
DU443 & 130.7 & 104.2 & 173.7 & 108.9 & 303.1 & n.d. \\
DU455 & 2169 & 1211 & 2892 & 2354 & inactive & n.d. \\
DU456 & 446.5 & 324.8 & 524.5 & 761.4 & 901.8 & n.d. \\
\hline
\end{tabular}

In the case of DU441, incorporating a tOctyl function in $\mathrm{R}^{2}$ position, demonstrated an excellent anti-leukemic activity (60.48 $\mathrm{nM} \mathrm{IC}_{50}$ value for MOLT-4). However, the tested DU443 with the same $\mathrm{R}^{2}$ substituent did not show a similar result (104.2 nM IC 50 value for MOLT-4) (Table 1). Accordingly, the substitution of $\mathrm{R}^{1}=\mathrm{OH}$ to $\mathrm{NH}_{2}$ (if $\mathrm{R}^{2}=$ tert-Octyl) decreased the measured biological effects 
(DU443). Incorporating an EWG group in the framework $\left(\mathrm{R}^{1}=4\right.$-F; DU283) led to less active antitumor behavior (146.2 $\mathrm{nM} \mathrm{IC}_{50}$ value for MOLT-4) (Table 1).

On the other hand, all 4-OH-phenyl substituted carboxamides proved to be very efficient against leukemia cell lines independent from the quality of $\mathrm{R}^{2}$ group. Each aliphatic functionalized, $t \mathrm{Bu}$, tOctyl besides $\mathrm{Cy}$ (DU442) compounds with $\mathrm{R}^{1}=4-\mathrm{OH}$ demonstrated high cytotoxic potential $\left(\mathrm{IC}_{50}\right.$ values were: $58.71 \mathrm{nM}, 51.03 \mathrm{nM}, 68.08 \mathrm{nM}$ on HL-60, MOLT-4, MV-4-11 cells, respectively (Table 1). Compounds (DU325, DU385, DU441, and DU442) with an $\mathrm{IC}_{50}$ value under $100 \mathrm{nM}$ were selected for subsequent experiments (Table 1 ).

Interestingly, the anti-leukemic behavior was diminished in those where a hydroxyl group was in ortho or meta position (DU455 and DU456). The effect on human primary fibroblasts used as control cells were much less cytotoxic reducing the viability maximum to $60 \%$, suggesting that the compounds reported herein were not as much as cytotoxic to non-malignant primary cells compared to leukemia cells (Table 1, Figure S7).

Cells were treated with imidazo[1,2-b]pyrazole-7-carboxamides in different concentrations (12.3 nM, $37 \mathrm{nM}, 111 \mathrm{nM}, 333 \mathrm{nM}, 1 \mu \mathrm{M}, 3 \mu \mathrm{M})$ in duplicates for $72 \mathrm{~h}$. Viability was examined by a resazurin assay, as described in Section 4.4. Materials and Methods. Hashmark (\#) labeled compounds were selected for further investigation. Dose response curves can be found in Figure S2 (HL-60), Figure S3 (MOLT-4), Figure S4 (MV-4-11), Figure S5 (THP-1), Figure S6 (K-562), Figure S7 (human primary fibroblasts). n.d. = not determined because the dose-response curves had a plateau around $0.7-0.6(70-60 \%)$ viability with maximum $30-40 \%$ effect.

Cytotoxicity was further investigated on 4T1 murine mammary carcinoma and MCF7 human breast adenocarcinoma cancer cells to determine whether the cytotoxic effect was specific against leukemia cells or the compounds possessed a general antitumor effect. The four selected compounds diminished the viability of both 4T1 and MCF7 cells in micromolar concentrations irrespective of the culture method (minimum $\mathrm{IC}_{50}=1.559 \mu \mathrm{M}$ of DU442 on MCF7 2D, maximum $\mathrm{IC}_{50}=10.8 \mu \mathrm{M}$ of DU325 on $4 \mathrm{~T} 13 \mathrm{D}$ (Table 2). The micromolar effective dose is not pharmacologically feasible compared to the nanomolar activity against leukemias, so imidazo[1,2-b]pyrazole-7-carboxamides were considered as potential anti-leukemic drug candidates instead of general antitumoral compounds.

Table 2. $\mathrm{IC}_{50}$ values $(\mu \mathrm{M})$ of analogs on $4 \mathrm{~T} 1$ and MCF7 breast cancer cells determined by resazurin assay upon treatment by imidazo[1,2-b]pyrazole-7-carboxamides.

\begin{tabular}{lcccc}
\hline & 4T1 2D & 4T1 3D & MCF7 2D & MCF7 3D \\
\hline DU325 & 3.938 & 10.800 & 3.445 & 8.216 \\
DU385 & 4.558 & 9.520 & 3.531 & 8.853 \\
DU441 & 3.363 & 4.914 & 3.032 & 3.537 \\
DU442 & 2.255 & 5.656 & 1.559 & 5.514 \\
\hline
\end{tabular}

Cells were treated with imidazo[1,2-b]pyrazole-7-carboxamides in different concentrations $(0.625 \mu \mathrm{M}, 1.125 \mu \mathrm{M}, 2.50 \mu \mathrm{M}, 5 \mu \mathrm{M}, 10 \mu \mathrm{M}, 20 \mu \mathrm{M})$ in duplicates for $72 \mathrm{~h}$. Viability was examined by resazurin assay as described in Section 4.4. Materials and Methods. Dose response curves can be found in Figure S8.

\subsection{Leukemia Cells Died by Apoptosis Upon Treatment by Imidazo[1,2-b]pyrazole-carboxamides}

To determine whether the anti-leukemic effect of imidazo[1,2-b]pyrazole-7-carboxamides relies on apoptosis or necrosis flow cytometry Annexin V propidium iodide staining was performed. Four compounds with $\mathrm{IC}_{50}$ values under $100 \mathrm{nM}$ have been selected for apoptotic studies on the most sensitive three cell lines (HL-60, MOLT-4, MV-4-11). Flow cytometry confirmed the absence of necrosis and revealed about $55 \%, 60 \%, 40 \%, 60 \%$ late apoptotic population (AnnV+/PI+) for MV-4-11 cells upon treatment by DU325, DU385, DU441, DU442, respectively (Figure 2A). While all compounds induced only $20 \%$ late apoptotic population (AnnV+/PI+) for HL-60 cells, the early apoptotic populations 
(AnnV+/PI-) for HL-60 cells were about 55\%, 50\%, 45\%, 50\% upon treatment by DU325, DU385, DU441, DU442, respectively (Figure 2B). This suggests that MV-4-11 cells are the most sensitive to drug candidates. MOLT- 4 cells showed only about $25-30 \%$ of total apoptotic population (early + late) indicating that lymphoid leukemias are less sensitive toward apoptosis than myeloid leukemia cells (Figure 1C).

\section{A}
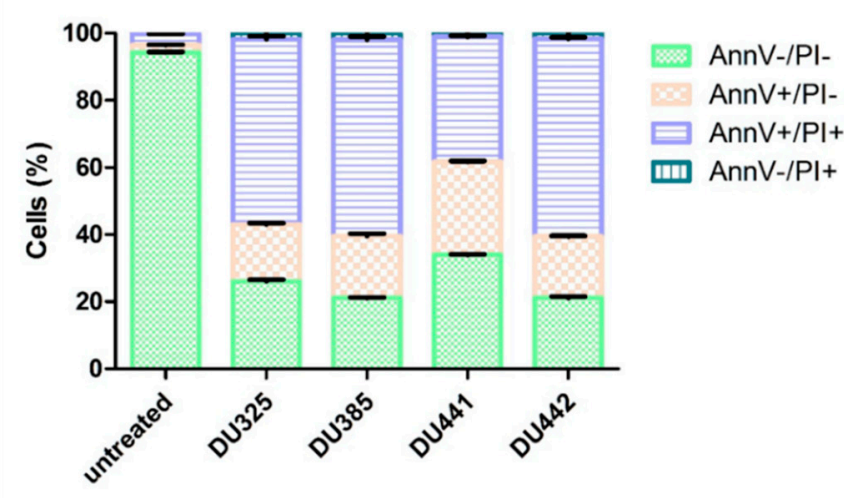

B

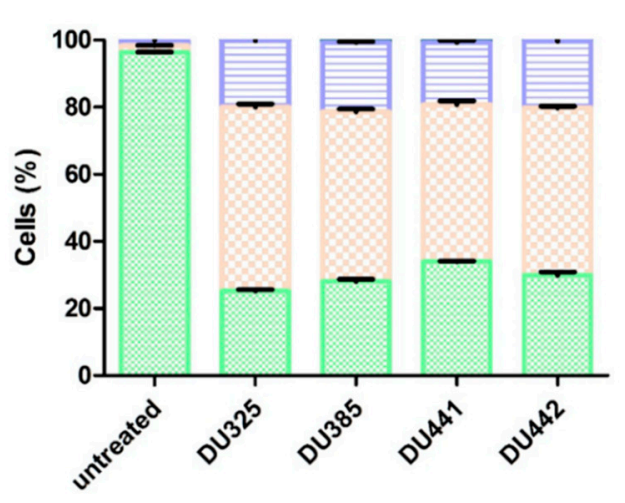

C

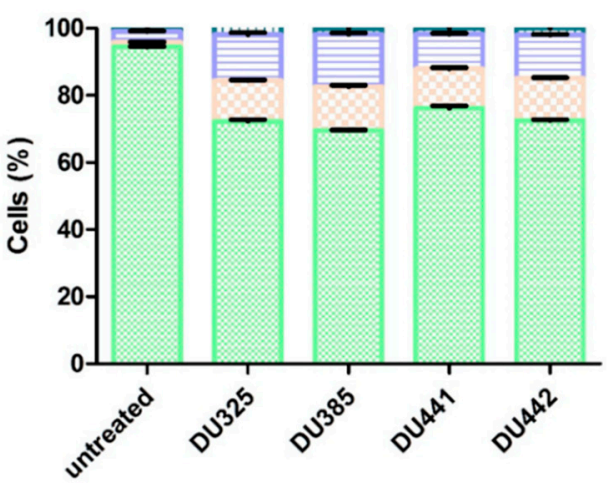

Figure 2. Imidazo[1,2-b]pyrazole-7-carboxamides induced phosphatidylserine exposure on human leukemia cells after 24 h. (A) MV-4-11, (B) HL-60, (C) MOLT-4 cells were incubated with $200 \mathrm{nM}$ imidazo[1,2-b]pyrazole-7-carboxamides as described in Section 4.5 Materials and Methods. The results are shown as arithmetic mean values of the summary of living cells (AnnV-/PI-), early (AnnV+/PI-) and late apoptotic cells (AnnV+/PI + ) of three samples \pm SD. Necrosis (AnnV-/PI+) did not occur. Corresponding flow cytometry data (SSC-FSC and AnnV/propidium iodide dot plots) can be found in Figure S9 (MV-4-11), Figure S10 (HL60), Figure S11 (MOLT-4).

\subsection{Toxicogenomic Data upon Treatment by Imidazo[1,2-b]pyrazole-7-carboxamide DU385}

To have a deep insight into the disturbance of cellular homeostasis of leukemic cells due to treatment by imidazo[1,2- $b$ ]pyrazole-7-carboxamides we have designed a toxicogenomic panel for a gene expression study (Table S1). The most sensitive MV-4-11 cells were treated by the most active lead compound DU385 as described in the Section 4.6 Materials and Methods. Functional categories of the investigated genes have been listed in Table S2. The toxicogenomic panel consists of genes which have been previously reported by Puskas et al. [18] and Zhang et al. in connection with drug induced cytotoxicity: Among others EGR1, GDF15, ATF3, FGF21 [19]. The expression of genes, published by Wang et al. involved in the differentiation and cytotoxicity of HL-60 cells induced by retinoids was also monitored in our study: SLC21A3, LGALS1, LBR, ALOX5AP, TXN, UBC, BCL2A1, CALR [20]. We implemented genes from our previous toxicogenomic study: ANXA2, GADD153, HSPA1A, $S O D 1$ [21]. G-protein coupled receptor 84 (GPR84), a key player of $\beta$-catenin mediated signaling 
maintaining leukemogenesis was also investigated [22]. Finally, the expression of interleukin-6 (IL6) and tumor necrosis factor alpha (TNF) inflammatory cytokines was investigated [23,24].

The determined temporal pattern of differential expression divided the tested genes into three groups as: Early (6 h) (Figure 3A), midterm (12 h) (Figure 3B), and late response ( $24 \mathrm{~h})$ genes upon treatment (Figure $3 \mathrm{C}$ ).

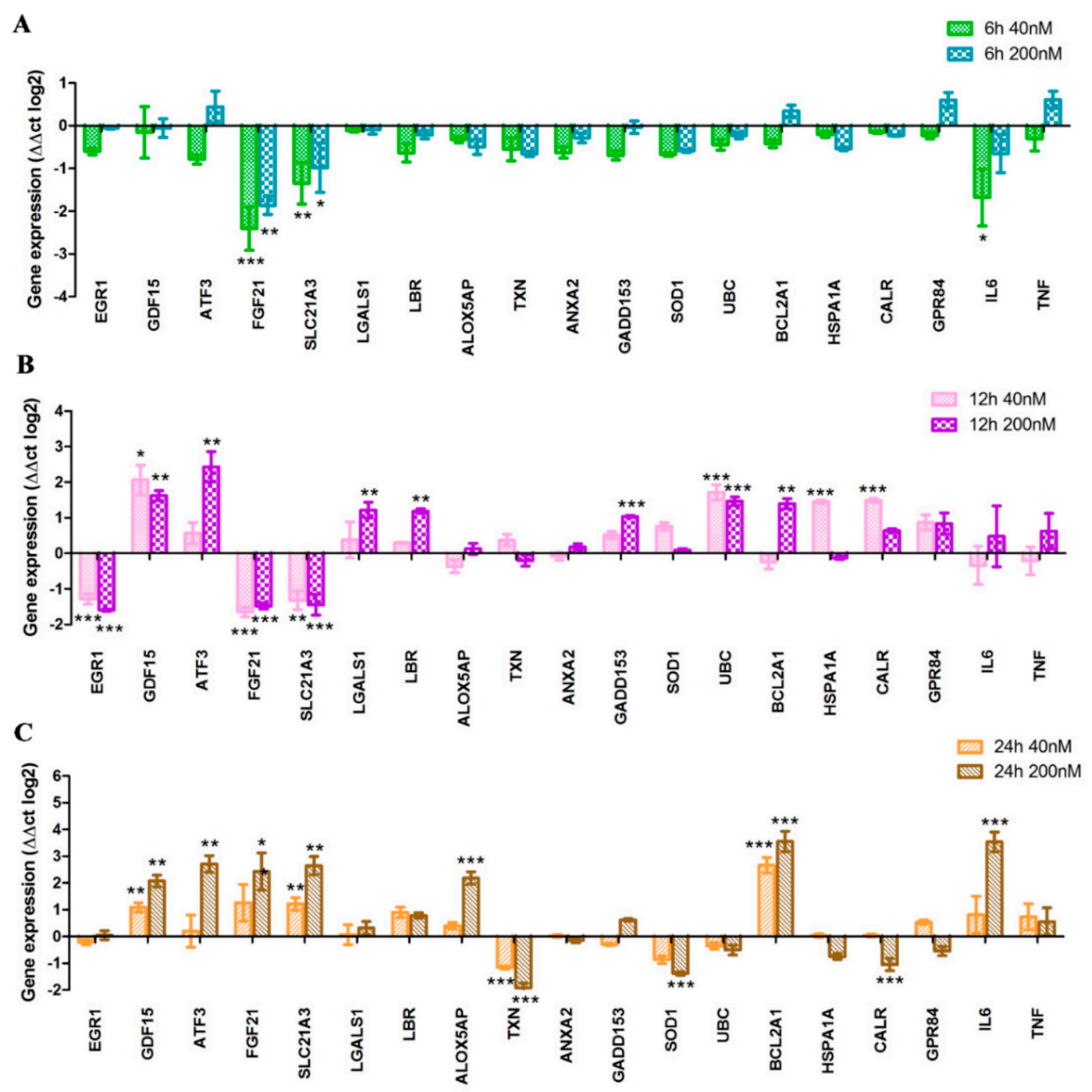

Figure 3. The expression of genes associated with drug induced cytotoxicity has been studied by quantitative real-time PCR after treatment with $40 \mathrm{nM}$ or $200 \mathrm{nM}$ DU385 compound for $6 \mathrm{~h}(\mathrm{~A}), 12 \mathrm{~h}$ (B), and $24 \mathrm{~h}(\mathrm{C})$, as described in Section 4.6 Materials and Methods. ${ }^{*} p<0.05,{ }^{* *} p<0.01,{ }^{* * *} p<0.001$.

As an early stress response, fibroblast growth factor 21 (FGF21), solute carrier organic anion transporter 1A2 (SLC21A3), and IL6 genes were repressed $5.6\left(\log _{2}=-2.5\right), 3.4\left(\log _{2}=-1.8\right)$, and $2.25\left(\log _{2}=-1.5\right)$ times upon $40 \mathrm{nM}$ treatment, respectively (Figure $3 \mathrm{~A}$ ). After $12 \mathrm{~h}$ incubation, not only FGF21 and SLC21A3, but also early growth response 1 (EGR1), showed decreased expression (2.8 times repression, $\log _{2}=-1.5$ ) (Figure 3B). It proved the concept that imidazo[1,2-b]pyrazole-7-carboxamides perturb the homeostasis of leukemia cells; nine genes (GDF15, ATF3, LGALS1, LBR, GADD153, UBC, BCL2A1, HSPA1A, CALR) associated with drug induced cytotoxicity have been significantly upregulated after $12 \mathrm{~h}$ stimulation (Figure $3 \mathrm{~B}$ ). Among the late response genes, some associated with oxidative stress were dysregulated, ALOX5AP increased 4 times $\left(\log _{2}=2\right)$, whilst TXN and SOD1 downregulated around 4 times $\left(\log _{2}=-2\right.$ and $\log 2=-1.8$, respectively) upon $200 \mathrm{nM} 24 \mathrm{~h}$ treatment (Figure 3C). The expression of the 
endoplasmic reticulum associated chaperon, calreticulin $(C A L R)$, also decreased $\left(\log _{2}=-1.1\right)$. Probably as a compensatory mechanism, the expression of FGF21 $\left(\log _{2}=2.4\right), S L C 21 A 3\left(\log _{2}=2.6\right)$ and $B C L 2 A 1$ elevated $(\log 2=3.5)$. Interleukin-6 (IL6) has been recently reported to contribute to the chemoresistance of pediatric AML [23], and we showed the overexpression $\left(\log _{2}=3.3\right)$ of IL6 after $24 \mathrm{~h}$ treatment (Figure 3C).

\subsection{Imidazo[1,2-b]pyrazole-7-carboxamide DU385 Exerted Oxidative Stress of MV-4-11 Cells}

Changes in the gene expression of oxidative stress-related genes (ALOX5AP, TXN, SOD1) opened the way for the investigation of cellular glutathione (GSH) level upon treatment. The luminescence in the assay is proportional with the GSH level, which can be reduced by reactive oxygen species (ROS) via oxidation or reaction with the thiol group [25]. Hydrogen peroxide validating the assay as a positive control was effective to decrease the GSH level prominently in $1 \mathrm{mM}$ after 6, 12, and $24 \mathrm{~h}$ (Figure 4A). The imidazo[1,2-b]pyrazole-7-carboxamide, DU385, was effective to generate ROS and the loss of GSH after $24 \mathrm{~h}$ to the $75 \%$ or $50 \%$ of the untreated cells with $40 \mathrm{nM}$ and $200 \mathrm{nM}$ treatment, respectively.

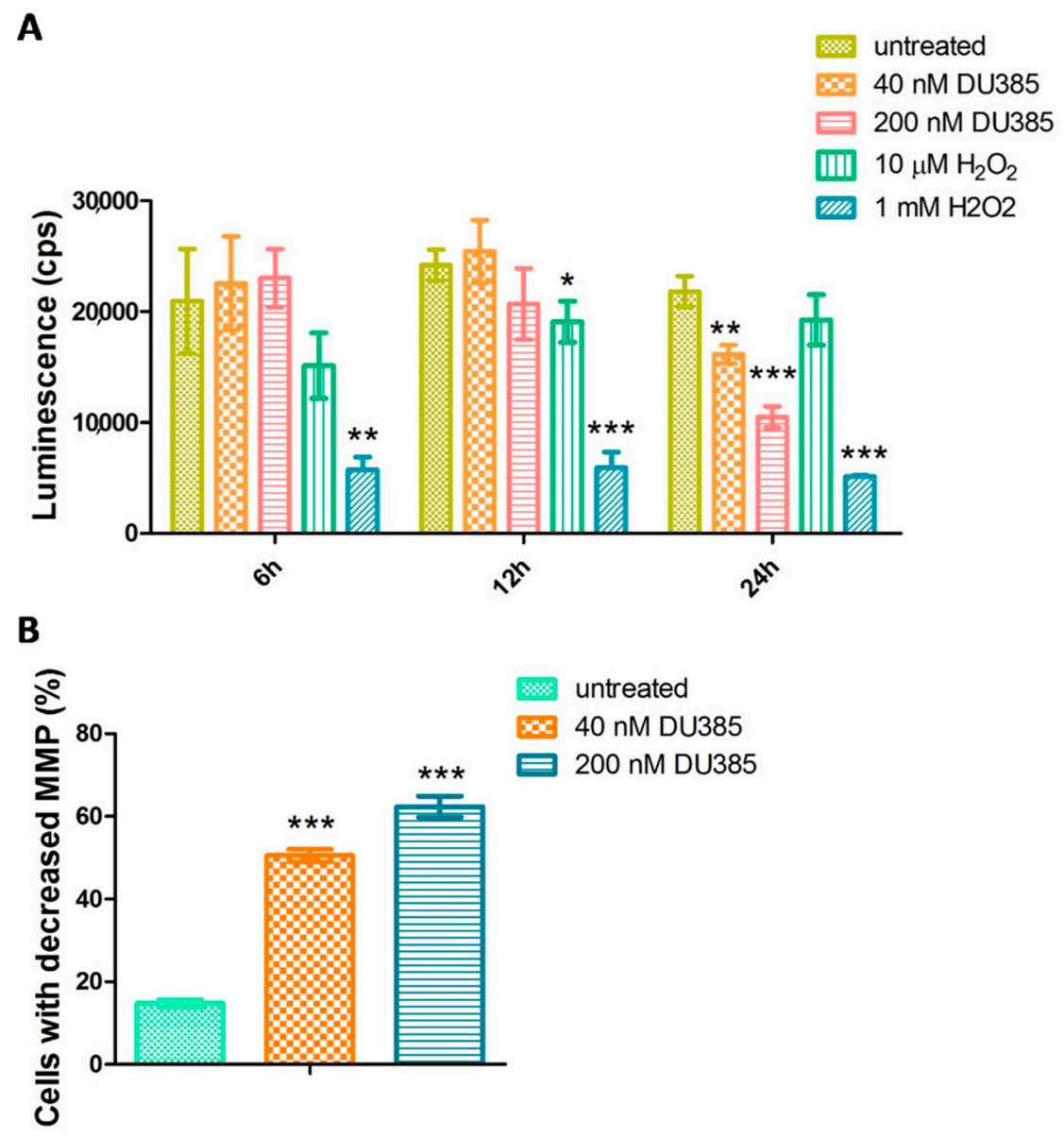

Figure 4. Imidazo[1,2-b]pyrazole-7-carboxamide DU385 exerted oxidative stress of MV-4-11 cells. Reduction of the glutathion (GSH) level (A) and the loss of the mitochondrial membrane potential (MMP) (B) were detected after $24 \mathrm{~h}$ as described in Section 4.7 Materials and Methods. ${ }^{*} p<0.05$, ** $p<0.01,{ }^{* * *} p<0.001$.

Since oxidative stress may subsequently confound mitochondrial homeostasis, the mitochondrial membrane potential was measured by JC- 1 assay. After $24 \mathrm{~h}$, the percentage of cells with decreased mitochondrial membrane potential three and four times increased after the treatment with $40 \mathrm{nM}$ or 200 nM DU385, respectively (Figure 4B, Figure S12). 


\section{Discussion}

We have shown the anti-leukemic effect of imidazo[1,2-b]pyrazole-7-carboxamides (Figure 1 and Figure S1) using the resazurin viability assay (Table 1, Figures S2-S6). The dose-response curves of the lead compound DU385 determined the following $\mathrm{IC}_{50}$ values: $16.54 \mathrm{nM}, 27.24 \mathrm{nM}$, and $32.25 \mathrm{nM}$ on HL-60, MOLT-4, MV-4-11 cells, respectively. Importantly, human primary fibroblasts were much less sensitive in the applied concentration range $(12.3 \mathrm{nM}-3 \mu \mathrm{M})$ suggesting selective cytotoxic effect, especially on leukemia cells (Table 1, Figure S7). Since carcinoma cells establish solid tumors in vivo, breast cancer cells were grown as three-dimensional (3D) spheroids compared to traditional tissue culture dishes (2D) (Table 2, Figure S8). Monolayer cultures ignore the role of microenvironmental factors, such as structural niche, with the plethora of molecular and cellular constituents [26]. Three dimensional cell cultures as drug discovery models better represent the in vivo situation like the partial oxygen tension, local $\mathrm{pH}$, or extracellular matrix composition [27]. Although monolayer cultures were much sensitive to treatment, the effect was much lower (between 1.5-10.8 $\mu \mathrm{M}$ $\mathrm{IC}_{50}$ values, Table 2) both in 2D and 3D models of murine $4 \mathrm{T1}$ or human MCF7 breast carcinoma cells, compared to the nanomolar $\mathrm{IC}_{50}$ values in leukemias (Table 1 ).

Incorporating $\mathrm{R}^{1}$ hydroxyl group in para position with a $t \mathrm{Bu}$ (DU385), tOctyl (DU441), or Cy (DU442) functions in $\mathrm{R}^{2}$ position, demonstrated an excellent anti-leukemic activity. Moreover, $\mathrm{R}^{1}$ para $\mathrm{NH}_{2}$ group combined with $\mathrm{R}_{2}$ tOctyl (DU325) had an anti-leukemic effect at nanomolar concentration. This potent anti-leukemic activity was diminished in those compounds where the $\mathrm{R}^{1}$ hydroxyl group was in ortho or meta position (DU455 and DU456), or the $\mathrm{R}^{2}$ tOctyl function was combined with the $\mathrm{R}^{1} \mathrm{NH}_{2}$ group (DU443). Incorporating an EWG group in the framework $\left(\mathrm{R}^{1}=4-\mathrm{F} ; \mathrm{DU} 283\right)$ led to a less active analog. All four selected compounds, DU325, DU385, DU441, and DU442 induced apoptosis of biphenotypic B myelomonocytic leukemia MV-4-11, acute promyelocytic leukemia HL-60, and the T-lymphoblastic leukemia MOLT-4 cells with different potential (Figure 2 and Figures S9-S11). None of the compounds induced necrosis. Myeloid cells were more sensitive to imidazo[1,2-b]pyrazole-7-carboxamides than the lymphoid MOLT-4, regarding the apoptotic process detected by flow cytometry.

Toxicogenomic screen was performed on MV-4-11 cells, the most susceptible cells for apoptosis. MV-4-11 cells were treated by the lead compound DU385. We have determined the expression pattern of early $(6 \mathrm{~h})$, midterm $(12 \mathrm{~h})$, and late response $(24 \mathrm{~h})$ genes upon imidazo[1,2-b]pyrazole-7-carboxamide stress (Figure 3). Early stress-related genes, FGF21 and SLC21A3 were repressed at both $6 \mathrm{~h}$ and $12 \mathrm{~h}$ treatments complemented with the decline of EGR1 expression at $12 \mathrm{~h}$ (Figure 3A,B). Early endoplasmic reticulum stress-associated genes, activating transcription factor 3 (ATF3), and DNA damage inducible transcript 3 (GADD153), elevated with chaperons like calreticulin (CALR) and heat shock protein family A (Hsp70) member 1A (HSPA1A) from $12 \mathrm{~h}$ of incubation. Other genes associated with differentiation and cell adhesion: Growth differentiation factor 15 (GDF15), galectin-1 (LGALS1), lamin B receptor (LBR) were upregulated at $12 \mathrm{~h}$. Polyubiquitin genes and Bcl family members regulate cell survival and apoptosis [28,29], ubiquitin $C$ has been described as a stress-response gene [30,31] activated at $12 \mathrm{~h}$ in MV-4-11 cells. The apoptosis regulator BCL2A1 (Bfl-1/A1) also elevated at 12 and $24 \mathrm{~h}$ upon stimulation, which has been described as anti-apoptotic [32], but also as pro-apoptotic via proteasome mediated turnover or calpain like cleavage [33]. During apoptosis detected at $24 \mathrm{~h}$, genes responsible for oxidative stress response were dysregulated, ALOX5AP increased, and TXN and SOD1 downregulated upon $200 \mathrm{nM}$ $24 \mathrm{~h}$ treatment (Figure 3C). Elevated levels of GDF15, ATF3, FGF21, SLC21A3, and IL6, were coupled with $20 \%$ early and $60 \%$ late apoptotic cells at $24 \mathrm{~h}$ (Figure $2 \mathrm{~A}$ ).

Changes in the gene expression of oxidative stress-related genes (ALOX5AP, TXN, SOD1) initiated the investigation of cellular GSH level. The amount of intracellular GSH dropped upon DU385 treatment only after $24 \mathrm{~h}$. The consistency in the GSH level with DU385 treatment after 6 and $12 \mathrm{~h}$ may indicate that the generation of ROS is not a fast stress response (like to $\mathrm{H}_{2} \mathrm{O}_{2}$ ), rather a well-organized process after $24 \mathrm{~h}$. Since oxidative stress induces mitochondrial dysfunction, and disturbance in the 
mitochondrial membrane potential can lead to apoptosis [34], the MMP was measured upon treatment by JC-1 assay. We have shown that mitochondria of MV-4-11 leukemia cells were depolarized when treated with $40 \mathrm{nM}$ or $200 \mathrm{nM}$ DU385 after $24 \mathrm{~h}$.

Since leukemia cells used in this study were immature cells, malignant cells of myeloid or lymphoid precursors, authors may speculate that cells differentiate after treatment and the mitochondrial pathway of apoptosis is followed after differentiation (Figure 4). Granulation (side scatter $=$ SSC) of the treated MV-4-11 (Figures S9 and S12), HL-60 (Figure S10) and MOLT-4 (Figure S11) cells increased after treatment, which proposes the differentiation concept. Apoptosis followed after differentiation to chemotherapy has already been published for immature leukemias [35-37], e.g., all-trans retinoic acid (ATRA) acts via that mechanism, which is applied in the clinical protocols [38]. Authors hypothesize that human fibroblasts and mouse 4T1 or human MCF7 breast carcinoma cells are less sensitive to DU385, probably because these are already differentiated cells with less apoptotic susceptibility or more complex anti-apoptotic mechanisms. Anyhow, further research is needed to reveal the cause of the sensitivity of immature leukemias to imidazo[1,2-b]pyrazole-7-carboxamide DU385.

In conclusion, imidazo[1,2- $b$ ]pyrazole-7-carboxamides reported herein, causing oxidative stress and apoptosis in nanomolar concentrations are promising drug candidates against human myeloid leukemias.

\section{Materials and Methods}

\subsection{Ethical Statement}

Participant informed consent was obtained prior to surgical intervention for the isolation of human primary fibroblasts. All tissue collection complied with the Guidelines of the Helsinki Declaration and was approved by the Regional and Institutional Research Ethics Committee $(2799,3517)$.

\subsection{Skin Biopsies and Cell Culture of Human Primary Fibroblasts}

Healthy volunteers (age 18-60 years) were enrolled into the study. The punch biopsies were taken from healthy subjects from the breast area undergoing plastic surgery. Primary fibroblasts were obtained from the skin by enzymatic digestion according to a standard protocol. Briefly, skin specimens were first washed in Salsol A solution (Human Rt, Gödöllő, Hungary) supplemented with $2 \%$ antibiotic/antimycotic solution (Sigma-Aldrich, St. Louis, MO, USA). Skin samples were then cut into narrow strips and incubated in Dispase solution (Roche Diagnostics, Mannheim, Germany) overnight at $4{ }^{\circ} \mathrm{C}$. The epidermis was subsequently separated from the dermis. Fibroblasts were obtained by incubating the dermis in Digestion Mix solution (Collagenase, Hyaluronidase and Deoxyribonuclease) for $2 \mathrm{~h}$ at $37^{\circ} \mathrm{C}$. Cell suspensions were filtered through a $100 \mu \mathrm{m}$ nylon mesh (BD Falcon, San Jose, CA, USA), and cells were pelleted by centrifugation (Thermo Fisher Scientific, Waltham, MA, USA, Megafuge 16). Fibroblasts were grown in low glucose DMEM/F12 medium containing 15\% FCS, 1\% antibiotic/antimycotic (PAA, Pasching, Austria) and 1\% L-glutamine solution (PAA). Fibroblasts were cultured at $37^{\circ} \mathrm{C}$ and $5 \% \mathrm{CO}_{2}$ in humidified conditions. Depending on the cell growth, the medium was changed every 2-4 days, and cells were passaged at $80 \%$ of confluence.

\subsection{Cell Culturing, 3D Spheroid Formation and Treatments}

The following cells were purchased from the American Type Culture Collection (ATCC, Manassas, WV, USA): HL-60 acute promyelocytic leukemia, THP-1 acute monocytic leukemia, MOLT-4 acute T-lymphoblastic leukemia, MV-4-11 biphenotypic B myelomonocytic leukemia, and K-562, erythroleukemia maintained in RPMI 10\% FCS (Gibco, Thermo Fisher Scientific, Waltham, MA, USA) using tissue culture dishes (Corning Life Sciences, Corning, NY, USA). The human breast adenocarcinoma MCF-7 and mouse mammary carcinoma 4T1 cells were also purchased from the ATCC. The MCF-7 cells were maintained in Dulbecco's Modified Eagle Medium/Nutrient Mixture 
F-12 (DMEM/F12) 10\% fetal calf serum (FCS, Gibco), and the 4T1 were maintained in Roswell Park Memorial Institute 1640 medium (RPMI-1640) with 10\% FCS. The pH of the cell culture media was controlled to be between 7.2-7.4 prior use. All used media were supplemented with 2 mM GlutaMAX, and $100 \mathrm{U} / \mathrm{mL}$ penicillin, $100 \mathrm{\mu g} / \mathrm{mL}$ streptomycin (Life Technologies, Carlsbad, CA, USA) before use. Cells were passed every three days and placed in a humidified incubator at $37{ }^{\circ} \mathrm{C} 5 \% \mathrm{CO}_{2}$ (Sanyo, Osaka, Japan).

The 3D spheroid production using pellet culture system was previously described by Johnstone, B et al. [39]. Briefly, the MCF-7 and 4T1 cells were gently detached from the conventional tissue culture flasks using trypsin, washed with PBS, counted, and then suspended to have 6000 cells in $100 \mu \mathrm{L}$ medium per well. The cellular suspensions were dispended into cell repellent, $\mathrm{U}$ shaped CellStar $^{\circledR} 96$ microplates (Cellstar ${ }^{\circledR}$ Cell-Repellent Microplate, Greiner Bio-One, Kermsmünster, Austria) and centrifuged at $1200 \mathrm{~g}$ for $10 \mathrm{~min}$. After spheroid formation (one spheroid/well), the spherical aggregates were directly used for viability assay without any detaching procedures and transfer steps. The cell repellent plates were incubated and maintained together with conventional $2 \mathrm{D}$ cell culture plates at $37^{\circ} \mathrm{C}$ in a humidified incubator in an atmosphere of $5 \% \mathrm{CO}_{2}$ (Sanyo).

Compounds were dissolved in dimethyl sulfoxide (DMSO) at $10 \mathrm{mM}$ concentration freshly before being used. Since DMSO can be toxic for cellular systems above $1 \%$, the stock solution was further diluted in serial dilutions in all cases in the appropriate cell culture media. The intermediate dilution of compounds for Figure 1 was $15 \mu \mathrm{M}(666.7 \times$ dilution) in the appropriate cell culture media, and it was three times serially diluted to $5 \mu \mathrm{M}, 1.667 \mu \mathrm{M}, 555 \mathrm{nM}, 185 \mathrm{nM}, 61.7 \mathrm{nM}$, then each intermediate dilution was further diluted $5 \times$ when it was added to the cells, so the treatments were $3 \mu \mathrm{M}, 1 \mu \mathrm{M}$, $333 \mathrm{nM}, 111 \mathrm{nM}, 37.5 \mathrm{nM}, 12.3 \mathrm{nM}$. The intermediate dilution of compounds for Figures 2-4 was $100 \mu \mathrm{M}(100 \times$ dilution $)$, it was serially diluted to $1 \mu \mathrm{M}(100 \times$ dilution $)$, and it was further diluted to $200 \mathrm{nM}(5 \times$ dilution), then each intermediate dilution was further diluted $5 \times$ when it was added to the cells, so the treatments were $200 \mathrm{nM}(5 \times), 40 \mathrm{nM}(5 \times)$.

\subsection{Resazurin Viability Assay}

The human primary fibroblasts, 4T1 or MCF7 cells (6000), and leukemia (HL-60, MOLT-4, MV-4-11, THP-1, K-562) cells $(20,000)$ were seeded into 96-well plates (Corning Life Sciences, Corning, NY, USA) in media. Adherent cells were cultured overnight before treatment. Effects of DU compounds were examined in the following concentrations: $12.3 \mathrm{nM}, 37 \mathrm{nM}, 111 \mathrm{nM}, 333 \mathrm{nM}, 1 \mu \mathrm{M}, 3 \mu \mathrm{M}$ in $100 \mu \mathrm{l}$ after $72 \mathrm{~h}$ incubation, for leukemias and control human primary fibroblasts. Treatment conditions were $0.625 \mu \mathrm{M}, 1.125 \mu \mathrm{M}, 2.50 \mu \mathrm{M}, 5 \mu \mathrm{M}, 10 \mu \mathrm{M}, 20 \mu \mathrm{M}$ for $4 \mathrm{~T} 1$ or MCF7 cells, for $72 \mathrm{~h}$. Viability assay was carried out as described previously in Reference [40]. Briefly, resazurin reagent (Sigma-Aldrich) was dissolved in PBS (pH 7.4) at $0.15 \mathrm{mg} / \mathrm{mL}$ concentration, sterile filtered $(0.22 \mu \mathrm{m}$, Merck Millipore), and aliquoted at $-20^{\circ} \mathrm{C}$. We applied resazurin $20 \mu \mathrm{L}$ stock to $100 \mu \mathrm{L} /$ well culture. After $2 \mathrm{~h}$ incubation at $37^{\circ} \mathrm{C}, 5 \% \mathrm{CO}_{2}$ (Sanyo) fluorescence (530nm excitation/580nm emission) was recorded on a multimode microplate reader (Cytofluor4000, PerSeptive Biosytems, Framingham, MA, USA). Viability was calculated with relation to untreated control cells (1 corresponds to $100 \%$ viability on the $y$ axis, Figures S2-S8), and blank wells containing media without cells. IC 50 values (50\% inhibiting concentration) were calculated by GraphPad Prism ${ }^{\circledR}$ (version 5.01, La Jolla, CA, USA).

\subsection{Detection of Phosphatidylserine Exposure}

Apoptosis was measured by flow cytometry as described previously in References [40,41]. Briefly, cells $(200,000)$ were plated in 24-well tissue culture plates (Corning Life Sciences) and treated with the indicated compounds at $200 \mathrm{nM}$ in $500 \mu \mathrm{L}$ media. After $24 \mathrm{~h}$, the supernatants were harvested. Cells were harvested with the corresponding supernatant and centrifuged down (2000 rpm, $5 \mathrm{~min}$, Eppendorf, Hamburg, Germany). Pellet was resuspended in Annexin V binding buffer (0.01 M HEPES, $0.14 \mathrm{M} \mathrm{NaCl}$ and $2.5 \mathrm{mM} \mathrm{CaCl}_{2}$ ). Annexin V-Alexa Fluor ${ }^{\circledR} 488$ (Life Technologies, 2.5:100) was added to the cells, which were then kept for $15 \mathrm{~min}$ in the dark at room temperature. Before the acquisition, 
propidium iodide (10 $\mu \mathrm{g} / \mathrm{mL}$, Sigma-Aldrich, St. Louis, MO, USA) was added in Annexin V binding buffer to dilute Annexin V-Alexa Fluor ${ }^{\circledR} 4885 \times$. Cells (20,000 events) were analyzed on a FACSCalibur flow cytometer using CellQuest software (version 3.3, Becton Dickinson, Franklin Lakes, NJ, USA). The percentage of the FL1 (530/30 nm filter, Annexin V-Alexa Fluor $\left.{ }^{\circledR} 488\right)$ positive, and FL3 (670 nm filter, propidium iodide) negative early apoptotic cells and FL1 positive and FL3 positive late apoptotic cells were determined. The total apoptotic population included both early and late apoptotic cells. Column charts were created by GraphPad Prism ${ }^{\circledR} 5$. Corresponding flow cyrometry data (SSC-FSC and AnnV/propidium iodide dot plots) can be found in Figure S9 (MV-4-11), Figure S10 (HL60), Figure S11 (MOLT-4).

\subsection{Quantitative-Real Time PCR}

MV-4-11 cells $\left(10 \times 10^{6}\right)$ were plated in $100 \mathrm{~mm}$ tissue culture dishes (Corning Life Sciences, Corning, NY, USA) in RPMI 10\% FCS. At different time points, cells were treated in $10 \mathrm{~mL}$ total volume with test compound DU385 at $40 \mathrm{nM}$ or $200 \mathrm{nM}$ for $6 \mathrm{~h}, 12 \mathrm{~h}$, or $24 \mathrm{~h}$. After treatment, nucleic acid preparation was done by using the RNA purification kit (Direct-zolTM RNA MiniPrep Kit, Zymo Research, Irvine, CA, USA), according to an already published protocol in Reference [40]. The quality and quantity of the isolated RNA were measured with NanoDrop1000 Version 3.8.1. (Thermo Fisher Scientific, Waltham, MA, USA). Reverse transcription from $3 \mu \mathrm{g}$ of total RNA was performed with the High-Capacity cDNA Archive Kit (Applied Biosystems, Foster, CA, USA) in a total volume of $30 \mu \mathrm{L}$ according to the manufacturer's protocol. After dilution with $130 \mu \mathrm{L}$ of ultrapure water (Applied Biosystems), cDNA was used as template for gene expression analysis. Quantitative real-time PCR (qRT-PCR) was performed on the LightCycler ${ }^{\circledR} 96$ System (Roche, Basel, Switzerland), using gene-specific primers with SYBR Green protocol, as described previously in Reference [42]. Briefly, for cycling, each $10 \mu \mathrm{L}$ PCR reaction contained $1 \mu \mathrm{L}$ cDNA (18.75 ng), $250 \mathrm{nM}$ primers, and $5 \mu \mathrm{L}$ qPCRBIO SyGreen Mix Lo-ROX (2×, PCR Byosystems, London, UK). Primer sequences and accession numbers are listed in Table S1. The PCR protocol was as follows: Enzyme activation at $95^{\circ} \mathrm{C}$ for $2 \mathrm{~min}$, 45 cycles of denaturation at $95^{\circ} \mathrm{C}$ for $10 \mathrm{~s}$, annealing at $60^{\circ} \mathrm{C}$, and extension at $60{ }^{\circ} \mathrm{C}$ for $10 \mathrm{~s}$. All the PCRs were performed with three replicates. After amplification, the melting curve was checked to verify the specificity of the PCR reactions. The $\mathrm{Ct}$ values were normalized to GAPDH gene for each time point. The presented relative gene expression ratios were $\Delta \Delta C T$ values $\left(\log _{2}\right)$. All values were presented as mean \pm standard deviation (SD).

\subsection{Detection of the Oxidative Stress}

Glutathion measurement was carried out as previously described in Reference [43]. MV-4-11 cells were plated $(2 \times 104)$ in a 96-well tissue culture plate (Corning Life Sciences, Corning, NY, USA), and were incubated with $40 \mathrm{nM}, 200 \mathrm{nM}$ DU385 compound or $10 \mu \mathrm{M}$ and $1 \mathrm{mM} \mathrm{H}_{2} \mathrm{O}_{2}$ (Sigma-Aldrich) in RPMI 10\% FCS for 6, 12, and $24 \mathrm{~h}$, in a humidified atmosphere of $95 \%$ air and $5 \% \mathrm{CO}_{2}$. Cells were harvested, washed in PBS, centrifuged (2000 rpm, $5 \mathrm{~min}$ ), suspended in $100 \mu \mathrm{L}$ PBS. Then, $50 \mu \mathrm{L}$ aliquots of prepared $2 \times$ GSH-GloTM Reagent (GSH-GloTM Glutathione assay; Promega, Madison, WI, USA) were added to $50 \mu \mathrm{L}$ of cells and incubated at room temperature in a black 96-well microtiter plate (Tomtec, Budapest, Hungary) for $30 \mathrm{~min}$. Thereafter, $100 \mu \mathrm{L}$ of reconstituted Luciferin Detection Reagent (Promega, Medison, WI, USA) was added to each well, and cells were incubated for $15 \mathrm{~min}$ further. The amount of light produced ( $\mathrm{cps}=$ counts per second) was detected by a plate reader (1420 Victor, Wallac, Perkin Elmer, Waltham, MA, USA). Data were visualized by a GraphPad Prism ${ }^{\circledR} 5$.

Mitochondrial membrane potential was measured as described previously in Reference [44]. Briefly, MV-4-11 cells $\left(2 \times 10^{5}\right)$ were plated in 24-well tissue culture plates (Corning Life Sciences, Corning, NY, USA) in RPMI 10\% FCS and were treated in $500 \mu \mathrm{L}$ media containing $40 \mathrm{nM}$ or $200 \mathrm{nM}$ DU385 compound. Untreated controls cells were supplemented with $500 \mu \mathrm{L}$ cell culture media. After $24 \mathrm{~h}$, the cells were harvested and centrifuged (2000 rpm, $5 \mathrm{~min}$ ). The pellet was suspended and incubated for $15 \mathrm{~min}$ in $5 \mu \mathrm{g} / \mathrm{mL} \mathrm{JC}-1$ 
(5,5',6,6'-tetrachloro-1,1' ${ }^{\prime}, 3,3^{\prime}$-tetraethylbenzimidazolocarbocyanine iodide, Chemodex, St. Gallen, Switzerland) containing media in final volume $300 \mu \mathrm{L}$ at $37^{\circ} \mathrm{C}$. Finally, using FL2 (cells with steady state mitochondria) $(585 / 42 \mathrm{~nm})-\mathrm{FL} 1$ (cells with depolarized mitochondria) $(530 / 30 \mathrm{~nm})$ channels, the red-green fluorescence intensity of $2 \times 10^{4}$ events was acquired immediately on a FACSCalibur flow cytometer. Data were analyzed using CellQuestTM software (CellQuest Pro v5.1, Becton Dickinson, Franklin Lakes, NJ, USA). Bar graphs showed the percentage of FL1 positive cells visualized by GraphPad Prism ${ }^{\circledR} 5$.

\subsection{Statistical Analysis}

Statistical analysis was performed using two-tailed, heteroscedastic Student's $t$-test to evaluate the statistical significance (set at ${ }^{*} p<0.05,{ }^{* *} p<0.01,{ }^{* * *} p<0.001$ ) between two given experimental groups: Pairwise comparison of each sample to the untreated control.

Supplementary Materials: The following are available online, Figure S1: Spectral data of imidazo[1,2-b]pyrazole carboxamides, Figure S2: Dose-response curves of imidazo[1,2-b]pyrazole-7-carboxamides on HL-60 cells, Figure S3: Dose-response curves of imidazo[1,2-b]pyrazole-7-carboxamides on MOLT-4 cells, Figure S4: Dose-response curves of imidazo[1,2-b]pyrazole-7-carboxamides on MV-4-11 cells, Figure S5: Dose-response curves of imidazo[1,2-b]pyrazole-7-carboxamides on THP-1 cells, Figure S6: Dose-response curves of imidazo[1,2-b]pyrazole-7-carboxamides on K-562 cells, Figure S7: Dose-response curves of imidazo[1,2-b]pyrazole-7-carboxamides on human primary fibroblast cells, Figure S8: Dose-response curves of imidazo[1,2-b]pyrazole-7-carboxamides on murine (4T1) and human (MCF7) breast cancer cells grown as a monolayer (2D) or spheroid (3D), Figure S9: Detection of phosphatidylserine exposure on MV-4-11 cells, Figure S10: Detection of phosphatidylserine exposure on HL-60 cells, Figure S11: Detection of phosphatidylserine exposure on MOLT-4 cells, Figure S12: Detection of the mitochondrial membrane potential.

Author Contributions: G.J.S., A.D., L.H.J., I.K. and L.G.P. conceived and designed the experiments. G.J.S., J.A.B., A.D., R.A., L.Z.F., V.L.V., I.M., E.K., B.G. and P.B. performed the experiments. G.J.S., A.D., L.H.J., I.K. and L.G.P. analyzed the data, G.J.S., A.D., L.G.P., L.H.J. and I.K. wrote the paper.

Funding: This research was funded by GINOP-2.3.2-15-2016-00030 and GINOP-2.3.2-15-2016-00001 from the National Research, Development and Innovation Office (NKFI), Hungary.

GJSz was supported BY the UNKP-18-4 New National Excellence Program of the Ministry of Human Capacities (UNKP-18-4-SZTE-73).

Conflicts of Interest: The authors declare no conflict of interest.

\section{References}

1. McGuire, S. World cancer report 2014. Geneva, switzerland: World health organization, international agency for research on cancer, who press, 2015. Adv. Nutr. 2016, 7, 418-419. [CrossRef] [PubMed]

2. Greaves, M. Leukaemia 'firsts' in cancer research and treatment. Nat. Rev. Cancer 2016, 16, $163-172$. [CrossRef] [PubMed]

3. Vardiman, J.W.; Thiele, J.; Arber, D.A.; Brunning, R.D.; Borowitz, M.J.; Porwit, A.; Harris, N.L.; Le Beau, M.M.; Hellstrom-Lindberg, E.; Tefferi, A.; et al. The 2008 revision of the world health organization (who) classification of myeloid neoplasms and acute leukemia: Rationale and important changes. Blood 2009, 114, 937-951. [CrossRef] [PubMed]

4. Bennett, J.M.; Catovsky, D.; Daniel, M.T.; Flandrin, G.; Galton, D.A.; Gralnick, H.R.; Sultan, C. Proposals for the classification of the acute leukaemias. French-American-British (fab) co-operative group. Br. J. Haematol. 1976, 33, 451-458. [CrossRef] [PubMed]

5. Bennett, J.M.; Catovsky, D.; Daniel, M.T.; Flandrin, G.; Galton, D.A.; Gralnick, H.R.; Sultan, C. Criteria for the diagnosis of acute leukemia of megakaryocyte lineage (M7). A report of the French-American-British cooperative group. Ann. Intern. Med. 1985, 103, 460-462. [CrossRef] [PubMed]

6. Collins, S.J. The HL-60 promyelocytic leukemia cell line: Proliferation, differentiation, and cellular oncogene expression. Blood 1987, 70, 1233-1244. [PubMed] 
7. Tasseff, R.; Jensen, H.A.; Congleton, J.; Dai, D.; Rogers, K.V.; Sagar, A.; Bunaciu, R.P.; Yen, A.; Varner, J.D. An effective model of the retinoic acid induced HL-60 differentiation program. Sci. Rep. 2017, 7, 14327. [CrossRef] [PubMed]

8. Mannarino, L.; Paracchini, L.; Craparotta, I.; Romano, M.; Marchini, S.; Gatta, R.; Erba, E.; Clivio, L.; Romualdi, C.; D'Incalci, M.; et al. A systems biology approach to investigate the mechanism of action of trabectedin in a model of myelomonocytic leukemia. Pharmacogenom. J. 2018, 18, 56-63. [CrossRef] [PubMed]

9. Mieczkowski, A.; Psurski, M.; Baginski, M.; Bieszczad, B.; Mroczkowska, M.; Wilczek, M.; Czajkowska, J.; Trzybinski, D.; Wozniak, K.; Wietrzyk, J. Novel (S)-1,3,4,12a-tetrahydropyrazino[2,1-c][1,4]benzodiazepine6,12(2H,11H)-dione derivatives: Selective inhibition of MV-4-11 biphenotypic b myelomonocytic leukemia cells' growth is accompanied by reactive oxygen species overproduction and apoptosis. Bioorg. Med. Chem. Lett. 2018, 28, 618-625. [CrossRef] [PubMed]

10. Battin, C.; Hennig, A.; Mayrhofer, P.; Kunert, R.; Zlabinger, G.J.; Steinberger, P.; Paster, W. A human monocytic NF-kB fluorescent reporter cell line for detection of microbial contaminants in biological samples. PLoS ONE 2017, 12, e0178220. [CrossRef] [PubMed]

11. Tsuchiya, S.; Yamabe, M.; Yamaguchi, Y.; Kobayashi, Y.; Konno, T.; Tada, K. Establishment and characterization of a human acute monocytic leukemia cell line (THP-1). Int. J. Cancer 1980, 26, 171-176. [CrossRef] [PubMed]

12. Liu, L.; Xu, F.; Chang, C.K.; He, Q.; Wu, L.Y.; Zhang, Z.; Li, X. Mycn contributes to the malignant characteristics of erythroleukemia through EZH2-mediated epigenetic repression of p21. Cell Death Dis. 2017, 8, e3126. [CrossRef] [PubMed]

13. Yang, B.; Wang, L.; Luo, X.; Chen, L.; Yang, Z.; Liu, L. SPAG6 silencing inhibits the growth of the malignant myeloid cell lines SKM-1 and K562 via activating p53 and caspase activation-dependent apoptosis. Int. J. Oncol. 2015, 46, 649-656. [CrossRef] [PubMed]

14. Karrouchi, K.; Radi, S.; Ramli, Y.; Taoufik, J.; Mabkhot, Y.N.; Al-Aizari, F.A.; Ansar, M. Synthesis and pharmacological activities of pyrazole derivatives: A review. Molecules 2018, 23, 134. [CrossRef] [PubMed]

15. Rahmati, A.; Eskandari-Vashareh, M.; Alizadeh-Kouzehrash, M. Synthesis of 3-(benzylideneamino)-2-phenyl -5H-imidazo[1,2-b]pyrazole-7-carbonitriles via a four-component condensation reaction. Tetrahedron 2013, 69, 4199-4204. [CrossRef]

16. Baviskar, A.T.; Madaan, C.; Preet, R.; Mohapatra, P.; Jain, V.; Agarwal, A.; Guchhait, S.K.; Kundu, C.N.; Banerjee, U.C.; Bharatam, P.V. N-fused imidazoles as novel anticancer agents that inhibit catalytic activity of topoisomerase II $\alpha$ and induce apoptosis in G1/S phase. J. Med. Chem. 2011, 54, 5013-5030. [CrossRef] [PubMed]

17. Demjen, A.; Alfoldi, R.; Angyal, A.; Gyuris, M.; Hackler, L., Jr.; Szebeni, G.J.; Wolfling, J.; Puskas, L.G.; Kanizsai, I. Synthesis, cytotoxic characterization, and sar study of imidazo[1,2- $b$ ]pyrazole-7-carboxamides. Arch. Pharm. 2018, 351, e1800062. [CrossRef] [PubMed]

18. Puskas, L.G.; Feher, L.Z.; Vizler, C.; Ayaydin, F.; Raso, E.; Molnar, E.; Magyary, I.; Kanizsai, I.; Gyuris, M.; Madacsi, R.; et al. Polyunsaturated fatty acids synergize with lipid droplet binding thalidomide analogs to induce oxidative stress in cancer cells. Lipids Health Dis. 2010, 9, 56. [CrossRef] [PubMed]

19. Zhang, J.D.; Berntenis, N.; Roth, A.; Ebeling, M. Data mining reveals a network of early-response genes as a consensus signature of drug-induced in vitro and in vivo toxicity. Pharmacogenom. J. 2014, 14, 208-216. [CrossRef] [PubMed]

20. Wang, J.; Fong, C.C.; Tzang, C.H.; Xiao, P.; Han, R.; Yang, M. Gene expression analysis of human promyelocytic leukemia HL-60 cell differentiation and cytotoxicity induced by natural and synthetic retinoids. Life Sci. 2009, 84, 576-583. [CrossRef] [PubMed]

21. Fabian, G.; Farago, N.; Feher, L.Z.; Nagy, L.I.; Kulin, S.; Kitajka, K.; Bito, T.; Tubak, V.; Katona, R.L.; Tiszlavicz, L.; et al. High-density real-time pcr-based in vivo toxicogenomic screen to predict organ-specific toxicity. Int. J. Mol. Sci. 2011, 12, 6116-6134. [CrossRef] [PubMed]

22. Dietrich, P.A.; Yang, C.; Leung, H.H.; Lynch, J.R.; Gonzales, E.; Liu, B.; Haber, M.; Norris, M.D.; Wang, J.; Wang, J.Y. GPR84 sustains aberrant $\beta$-catenin signaling in leukemic stem cells for maintenance of mll leukemogenesis. Blood 2014, 124, 3284-3294. [CrossRef] [PubMed] 
23. Stevens, A.M.; Miller, J.M.; Munoz, J.O.; Gaikwad, A.S.; Redell, M.S. Interleukin-6 levels predict event-free survival in pediatric aml and suggest a mechanism of chemotherapy resistance. Blood Adv. 2017, 1, 1387-1397. [CrossRef] [PubMed]

24. Sedger, L.M.; McDermott, M.F. Tnf and tnf-receptors: From mediators of cell death and inflammation to therapeutic giants-Past, present and future. Cytokine Growth Factor Rev. 2014, 25, 453-472. [CrossRef] [PubMed]

25. Sies, H. Glutathione and its role in cellular functions. Free Radic. Biol. Med. 1999, 27, 916-921. [CrossRef]

26. Zanoni, M.; Piccinini, F.; Arienti, C.; Zamagni, A.; Santi, S.; Polico, R.; Bevilacqua, A.; Tesei, A. 3D tumor spheroid models for in vitro therapeutic screening: A systematic approach to enhance the biological relevance of data obtained. Sci. Rep. 2016, 6, 19103. [CrossRef] [PubMed]

27. Verjans, E.T.; Doijen, J.; Luyten, W.; Landuyt, B.; Schoofs, L. Three-dimensional cell culture models for anticancer drug screening: Worth the effort? J. Cell Physiol. 2018, 233, 2993-3003. [CrossRef] [PubMed]

28. Broemer, M.; Meier, P. Ubiquitin-mediated regulation of apoptosis. Trends Cell Biol. 2009, 19, $130-140$. [CrossRef] [PubMed]

29. Ottina, E.; Tischner, D.; Herold, M.J.; Villunger, A. A1/Bfl-1 in leukocyte development and cell death. Exp. Cell Res. 2012, 318, 1291-1303. [CrossRef] [PubMed]

30. Bianchi, M.; Crinelli, R.; Arbore, V.; Magnani, M. Induction of ubiquitin C (UBC) gene transcription is mediated by HSF1: Role of proteotoxic and oxidative stress. FEBS Open Bio 2018, 8, 1471-1485. [CrossRef] [PubMed]

31. Ryu, K.Y.; Maehr, R.; Gilchrist, C.A.; Long, M.A.; Bouley, D.M.; Mueller, B.; Ploegh, H.L.; Kopito, R.R. The mouse polyubiquitin gene UBC is essential for fetal liver development, cell-cycle progression and stress tolerance. EMBO J. 2007, 26, 2693-2706. [CrossRef] [PubMed]

32. Jenal, M.; Batliner, J.; Reddy, V.A.; Haferlach, T.; Tobler, A.; Fey, M.F.; Torbett, B.E.; Tschan, M.P. The anti-apoptotic gene BCL2A1 is a novel transcriptional target of PU.1. Leukemia 2010, 24, 1073-1076. [CrossRef] [PubMed]

33. Kucharczak, J.F.; Simmons, M.J.; Duckett, C.S.; Gelinas, C. Constitutive proteasome-mediated turnover of Bfl-1/A1 and its processing in response to TNF receptor activation in FL5.12 pro-B cells convert it into a prodeath factor. Cell Death Differ. 2005, 12, 1225-1239. [CrossRef] [PubMed]

34. Circu, M.L.; Aw, T.Y. Glutathione and modulation of cell apoptosis. Biochim. Biophys. Acta 2012, 1823, 1767-1777. [CrossRef] [PubMed]

35. Watson, R.W.; Rotstein, O.D.; Parodo, J.; Bitar, R.; Hackam, D.; Marshall, J.C. Granulocytic differentiation of HL-60 cells results in spontaneous apoptosis mediated by increased caspase expression. FEBS Lett. 1997, 412, 603-609. [CrossRef]

36. Doyle, B.T.; O’Neill, A.J.; Fitzpatrick, J.M.; Watson, R.W. Differentiation-induced HL-60 cell apoptosis: A mechanism independent of mitochondrial disruption? Apoptosis 2004, 9, 345-352. [CrossRef] [PubMed]

37. Doyle, B.T.; O’Neill, A.J.; Newsholme, P.; Fitzpatrick, J.M.; Watson, R.W. The loss of iap expression during HL-60 cell differentiation is caspase-independent. J. Leukoc. Biol. 2002, 71, 247-254. [PubMed]

38. Brown, G.; Hughes, P. Retinoid differentiation therapy for common types of acute myeloid leukemia. Leukemia Res. Treat. 2012, 2012, 939021. [CrossRef] [PubMed]

39. Johnstone, B.; Hering, T.M.; Caplan, A.I.; Goldberg, V.M.; Yoo, J.U. In vitro chondrogenesis of bone marrow-derived mesenchymal progenitor cells. Exp. Cell Res. 1998, 238, 265-272. [CrossRef] [PubMed]

40. Szebeni, G.J.; Balazs, A.; Madarasz, I.; Pocz, G.; Ayaydin, F.; Kanizsai, I.; Fajka-Boja, R.; Alfoldi, R.; Hackler, L., Jr.; Puskas, L.G. Achiral mannich-base curcumin analogs induce unfolded protein response and mitochondrial membrane depolarization in panc-1 cells. Int. J. Mol. Sci. 2017, 18, 2105. [CrossRef] [PubMed]

41. Molnar, J.; Szebeni, G.J.; Csupor-Loffler, B.; Hajdu, Z.; Szekeres, T.; Saiko, P.; Ocsovszki, I.; Puskas, L.G.; Hohmann, J.; Zupko, I. Investigation of the antiproliferative properties of natural sesquiterpenes from artemisia asiatica and onopordum acanthium on HL-60 cells in vitro. Int. J. Mol. Sci. 2016, 17, 83. [CrossRef] [PubMed] 
42. Szebeni, G.J.; Tancos, Z.; Feher, L.Z.; Alfoldi, R.; Kobolak, J.; Dinnyes, A.; Puskas, L.G. Real architecture for $3 \mathrm{D}$ tissue (raft) culture system improves viability and maintains insulin and glucagon production of mouse pancreatic islet cells. Cytotechnology 2017, 69, 359-369. [CrossRef] [PubMed]

43. Nagy, L.I.; Molnar, E.; Kanizsai, I.; Madacsi, R.; Ozsvari, B.; Feher, L.Z.; Fabian, G.; Marton, A.; Vizler, C.; Ayaydin, F.; et al. Lipid droplet binding thalidomide analogs activate endoplasmic reticulum stress and suppress hepatocellular carcinoma in a chemically induced transgenic mouse model. Lipids Health. Dis. 2013, 12, 175. [CrossRef] [PubMed]

44. Kanizsai, I.; Madacsi, R.; Hackler, L., Jr.; Gyuris, M.; Szebeni, G.J.; Huzian, O.; Puskas, L.G. Synthesis and cytoprotective characterization of 8-hydroxyquinoline betti products. Molecules 2018, 23, 1934. [CrossRef] [PubMed]

Sample Availability: Samples of the compounds are available from the authors.

(C) 2018 by the authors. Licensee MDPI, Basel, Switzerland. This article is an open access article distributed under the terms and conditions of the Creative Commons Attribution (CC BY) license (http:/ / creativecommons.org/licenses/by/4.0/). 